\title{
PENDIDIKAN KESEHATAN KEPATUHAN MINUM OBAT PADA LANSIA DENGAN DIABETES MELITUS TIPE II DI UPT PELAYANAN SOSIAL LANJUT USIA BINJAI
}

\section{Sio Citra Manurung ${ }^{1}$, Resmi Pangaribuan ${ }^{2^{*}}$, Jemaulana Tarigan ${ }^{3}$}

\author{
${ }^{1}$ Mahasiwa Program Studi Keperawatan Akper Kesdam I/BB Medan \\ Email: siocitra0@gmail.com \\ 2Dosen Program Studi Keperawatan Akper Kesdam I/BB Medan \\ Email:resmipangaribuan131417@gmail.com \\ ${ }^{3}$ Dosen Program Studi Keperawatan Akper Kesdam I/BB Medan \\ Email:jemaulana1973gmail.com
}

\section{ABSTRACT: HEALTH EDUCATION ON MEDICINE COMPLIANCE IN THE ELDERLY WITH DIABETES MELLITUS TYPE II AT THE UPT PELAYANAN SOSIAL LANJUT USIA BINJAI}

Introduction: The world organization predicted the increase number of people with diabetes mellitus from 8.4 million in 2000 to around 21.3 million in 2030 . Diabetes mellitus is a group of metabolic diseases characterized by hyperglycemia that occur due to the abnormalities in insulin secretion, insulin action, or both. The aging process is continuous and natural experienced by all the living things. The adherence of type 2 Diabetes Mellitus patients is generally defined as the level of behavior of a person receiving treatment to follow the diet plan, take medication and carry out a lifestyle in accordance with the recommendations of health care providers. Health education is aimed to help people take control of their own health by influencing, enabling and reinforcing the decision or action according to their own values and goals.

Method: The study used descriptive case study method by carried out 2 patients as the subject. The results of the study found that the patients had the lack of knowledge about the need for drug compliance related to non-adherence to taking the medication.

Result: The intervention and implementation were implemented by conducting the health education on medication adherence in stages with the results obtained that the patient appeared to take the drug on time and their blood sugar level was within the normal range.

Conclusion: By conducting the health education about medication adherence for the elderly for 3 days, it could increase the knowledge and change their obedience behavior and follow the rules of taking the medication.

Keywords: Lack of Knowledge, Diabetes Mellitus, Health Education, Elderly, Medication Adherence.

\section{INTISARI: PENDIDIKAN KESEHATAN KEPATUHAN MINUM OBAT PADA LANSIA DENGAN DIABETES MELITUS TIPE II DI UPT PELAYANAN SOSIAL LANJUT USIA BINJAI}

Latar Belakang: Organisasi dunia memprediksi kenaikan jumlah penyandang Diabetes Melitus dari 8,4 juta pada tahun 2000 menjadi sekitar 21,3 juta pada tahun 2030. Diabetes Melitus merupakan suatu kelompok penyakit metabolik dengan karaktersistik hiperglikemia yang terjadi karena kelainan sekresi insulin, 
kerja insulin atau kedua duanya. Proses menua yaitu proses yang terus-menerus kelanjutan secara alamiah dan dialami oleh semua makhluk hidup. Kepatuhan pada pasien Diabetes Melitus tipe 2 secara umum di definisikan sebagai tingkatan perilaku seseorang yang mendapatkan pengobatan untuk menjalankan diet, minum obat dan melaksanakan gaya hidup sesuai dengan rekomendasi pemberi pelayanan kesehatan. Pendidikan kesehatan bertujuan untuk membantu orangorang mengontrol kesehatan mereka sendiri dengan mempengaruhi, memungkinkan dan menguatkan keputusan atau tindakan sesuai dengan nilai dan tujuan mereka sendiri.

Metode: yang digunakan adalah deskriptif studi kasus. Subjek penelitian dilakukan pada kedua pasien.

Hasil: Hasil pengkajian diperoleh kurang pengetahuan tentang kebutuhan kepatuhan minum obat berhubungan dengan ketikdakpatuhan minum obat, intervensi dan implementasi adalah melakukan pendidikan kesehatan kepatuhan minum obat secara bertahap dengan hasil yang diperoleh klien tampak meminum obat tepat waktu dan kadar gula darah dibatas normal.

Kesimpulan: Dengan dilakukannya pendidikan kesehatan tentang kepatuhan minum obat kepada lansia selama 3 hari dapat meningkatkan pengetahuan dan dapat mengubah perilaku lansia menjadi patu dan mengikuti aturan minum obat.

Kata kunci: Kurang pengetahuan, diabetes mellitus, pendidikan kesehatan, lansia, kepatuhan minum obat

\section{PENDAHULUAN}

Meningkatnya prevalensi diabetes melitus di beberapa negara berkembang, akibat peningkatan kemakmuran dinegara bersangkutan, akhir akhir ini banyak disoroti. Peningkatan pendapatan perkapita dan perubahan gaya hidup dikota kota besar, menyebabkan peningkatan prevalensi penyakit degeneratif, seperti penyakit jantung koroner (PJK), hipertensi, hiperlipidemia, diabetes dan lain lain. Tetapi data epidemologi dinegara berkembang memang masih belum banyak, hal ini disebabakan penelitian epidemiologi sangat mahal biayanya. Oleh karena itu angka prevalensi yang dapat ditelusuri terutama berasaal dari negara maju Suddarth (2019).

Menurut American Diabates Association (2018), Diabetes Melitus merupakan suatu kelompok penyakit metabolik dengan karaktersistik hiperglikemia yang terjadi karena kelainan sekresi insulin, kerja insulin atau kedua duanya. Hiperglikemia kronik pada diabetes berhubungan dengan kerusakaan jangka panjang, disfungsi atau kegagalan beberapa organ tubuh, terutama ginjal, syaraf, jantung dan pembuluh darah, sedang sebelum nya WHO berkata bahwa DM merupakan suatu yang tidak dapat dituangkan dalam satu jawaban yang jelas dan singkat secara singkat.

Proses menua merupakan proses yang terus-menerus kelanjutan secara alamiah dan umumnya dialami oleh semua makhluk hidup. Misalnya, dengan terjadinya kehilangan jaringan kehilangan jaringan pada otot susunan syaraf, dan jaringan lainya. Kecepatan proses menua setiap individu pada organ tubuh tidak akan sama. Adakalanya seseorang belum tergolong lanjut usia /masih muda tetepi sudah menunjukkan kekurangan yang mencolok.

WHO (2018) dan Undang-undang Nomor 13 Tahun 1998 tentang kesejahterahan lanjut usia pada Bab 
1 Ayat 2 menyebutkan bahwa umur 60 thaun adalah usia pemulaan tua. Menua bukannla suatu penyakit, tetapi merupakan proses uang berangsur angsur mengakibatkan perubahan yang kumulatif, merupakan proses yang menurunnya daya tahan tubuh dalam menghadapi rangsangan dari dalam dan luar tubuh yang berakhir dengan kematian.

World Health Organization (WHO) 2018, memprediksi kenaikan jumlah penyandang DM dari 8,4 juta pada tahun 2000 menjadi sekitar 21,3 juta pada tahun 2030. International Diabetes Federation (IDF) menyatakan bahwa lebih dari 371 juta orang di dunia yang berumur 20-79 tahun memiliki diabetes. Indonesia termasuk Negara dengan prevalensi diabetes tertinggi, yaitu urutan ke-7 di bawah China, India, USA, Brazil, Rusia, dan Mexico.

Prevalensi penyakit Diabetes Melitus $\geq 15$ tahun di Provinsi Sumatera Utara pada tahun 2013 berkisar $6,9 \%$ dan meningkat pada tahun 2018 menjadi 8,5\% (Riskesdas, 2018).

Berdasarkan hasil penelitian dari Kurniawaty (2016), dkk menyatakan bahwa faktor yang berhubungan dengan kejadian diabetes melitus tipe 2. Berdasarkan hasil ini variabel umur $\geq 50$ dapat meningkatkan kejadian DM tipe 2 karena penuaan menyebabkan menurunnya sensitivitas insulin dan menurunnya fungsi tubuh untuk metabolisme glukosa. Hal tersebut didukung hasil penelitian yang serupa oleh Suastika di Bali didapatkan bahwa prevalensi DM pada kelompok usia tua lebih tinggi tiga kali lipat dibandingkan dengan kelompok yang lebih muda.

Kepatuhan pengobatan adalah sejauh mana perilaku seseorang minum obat, mengikuti diet, dan atau menjalankan gaya hidup, sesuia dengan rekomendasi yang disepakati dari penyedia layanan kesehatan. Kepatuhan merupakan salah faktor yang sangat penting dalam keberhasilan terapi seorang pasien termasuk pasien DM tipe 2 . Kepatuhan menjadi persoalan yang perlu mendapatkan perhatian pada pasien DM tipe 2. Berbagai penelitian melaporkan rendahnya kepatuhan pada pasien tersebut (Rizki dkk , 2020).

Menurut Fandinata, pada tahun Juni 2020 bahwa Kepatuhan pada pasien Diabetes Melitus tipe 2 secara umum didefinisikan sebagai tingkatan perilaku seseorang yang mendapatkan pengobatan untuk menjalankan diet, minum obat dan melaksanakan gaya hidup sesuai dengan rekomendasi pemberi pelayanan kesehatan. Pasien yang tidak paham mengenai penyakit Diabetes Melitus, sering tidak patuh dalam melaksanakan pengobatan Diabetes Melitus. Keberhasilan pengobatan Diabetes Melitus sangat bergantung pada kepatuhan pasien minum obat. Beberapa penelitian sebelumnya tentang hubungan antara pengetahuan dan kepatuhan minum obat menunjukkan hasil yang berbeda-beda. Berdasarkan data diatas kepatuhan minum obat dengan Diabetes Melitus dapat mempengaruhi pengetahauan tentang Diabetes Melitus. Dari hasil observasi yang dilakukan, ada lansia yang mengalami kesulitan dalam mengingat kepatuhan minum obat yang dialaminya. Penatalaksanaan yang dilakukan pendidikan kesehatan kepatuhan minum.

Berdasarkan survey pendahuluan yang dilakukan peneliti di UPT pelayanan sosial lanjut usia Binjai pada tanggal 11 Desember 2020 di peroleh data jumlah pasien di UPT pelayanan sosial lanjut usia Binjai sebanyak 176 jiwa yang terdiri dari 90 lansia perempuan dan 86 lansia laki-laki, Terdiagnosa menderita DM tipe II sebanyak 30 orang terdiri dari 
18 orang perempuan, 12 laki-laki yang tinggal di wisma, UPT.

Berdasarkan fenomena diatas dengan diagnosa kurang pengetahuan mengenai penyakit, prognosis, dan kebutuhan pengobatan berhubungan dengan kurang mengingat maka peneliti ingin melakukan Studi Kasus pendidikan kesehatan kepatuhan minum obat Diabetes Melitus tipe 2 Pada Lansia Di Upt Pelayanan Lanjut Usia Binjai.

\section{METODE PENELITIAN}

Rancangan Penelitian

Penelitian ini merupakan
penelitian deskriptif dengan
rancangan studi kasus pendidikan kesehatan kepatuhan minum obat pada lansia dengan diagnosa Diabetes Melitus tipe 2 dengan menggunakan pendekatan proses keperawatan yang dilakukan peneliti meliputi tahapan sebagai berikut;

a. Pengkajian:Peneliti pengumpulan data secara auto dan alloanamnesa baik yang bersumber dari responden/pasien, keluarga pasien, maupun lembar status pasien, b. Diagnosis keperawatan : Peneliti melakukan analisis terhadap semua data yang diperoleh sehingga didapatkan diagnose keperawatan yang di angkat yaitu Kurang pengetahuan (kebutuhan belajar), mengenai penyakit, prognosis dan kebutuhan pengobatan c. Intervensi keperawatan : Peneliti menyusun rencana tindakan keperawatan untuk mengatasi masalah keperawatan yang terjadi yaitu, d. Implementasi keperawatan : Peneliti melakukan renc Kurang pengetahuan (kebutuhan belajar), mengenai penyakit, prognosis dan kebutuhan pengobatanana tindakan yang telah disusun, e. Evaluasi keperawatan :Peneliti melakukan penilaian tindakan keperawatan yang telah dilakukan dalam mengatasi masalah yang terjadi.
Subyek Penelitian

1. Subjek yang digunakan adalah 2 pasien dengan 2 kasus dengan masalah keperawatan yang sama. Studi kasus berjudul Kurang pengetahuan (kebutuhan belajar), mengenai penyakit, prognosis dan kebutuhan pengobatan

Adapun kriteria inklusi dan eksklusipada penelitian ini adalah :

1. Kriteria Inklusi:

a. Penderita Diabetes Melitus Tipe 2 yang bersedia menjadi responden, b)Penderita Diabetes Melitus Tipe 2dengan jenis kelamin laki-laki dan perempuan, c) Penderita Diabetes Melitus tipe 2 dengan umur $>60$ tahun, dan d) Pasien Diabetes Melitus tipe 2 yang mengalami Kurang pengetahuan (kebutuhan belajar), mengenai penyakit, prognosis dan kebutuhan pengobatan.

2. Kriteria ekslusi :

a) Penderita Diabetes Melitus yang memliki komplikasi, b) Penderita Diabetes Melitus yang tidak bersedia menjadi responden.

Fokus Studi

Studi kasus ini terfokus Kurang pengetahuan (kebutuhan belajar), mengenai penyakit, prognosis dan kebutuhan pengobatandi UPT Pelayanan Sosial Usia Lanjut Binjai. Instrumen Penelitian

Alat atau instrument pengumpulan data dalam wawancara menggunakan format pengkajian asuhan keperawatan gerontik sedangkan dalam observasi menggunakan alat-alat seperti tensi meter, stetoskop, dan timbangan.

Metode Pengumpulan Data

Pengumpulan data dalam karya tulis studi kasus ini adalah dengan menggunakan instrument Biofisiologis, Observasi, Wawancara dan Kuesioner..

Metode pengumpulan data yang digunakan yaitu: 
a. Wawancara : Hasil anamnesis berisi tentang identitas klien, keluhan utama, riwayat penyakit sekarang-dahulu-keluarga dan lainlain. Sumber data dari klien, keluarga dan perawat lainnya, b. Observasi dan Pemeriksaan Fisik : Observasi dan Pemeriksaan Fisik dengan pendekatan IPPA : inspeksi, palpasi, perkusi, auskultasi pada klien, c. Studi Dokumentasi dan Angket : Studi dokumentasi dan angket di dapatkan dari hasil pemeriksaan diagnostik dan data lain yang relevan.

Analisa Data dan Penyajian Data

Penyajian data yang digunakan yaitu dengan penyajian secara terstruktural ataupun berbentuk narasi yang didukung dari data yang diperoleh dari klien.

Analisa data dilakukan dengan cara mengemukakan fakta, selanjutnya membandingkan dengan teori yang ada dan selanjutnya dituangkan dalam opini pembahasan. Teknik analisis yang digunakan dengan cara menarasikan jawaban-jawaban dari penelitian yang diperoleh dari hasil interpretasi wawancara mendalam yang dilakukan untuk menjawab rumusan masalah penelitian. Teknik analisis digunakan dengan cara observasi oleh penelito dan studi dokumentasi yang menghasilkan data untuk selanjutnya diinterprestasikan oleh peneliti dibandingkan teori yang ada sebagai bahan untuk memberikan rekomendasi dalam intervensi tersebut. Urutan dalam analisis adalah :

a) Pengumpulan data : Data dikumpulkan dari hasil wawancara,a) observasi, dokumentasi. Hasil ditulis dalam bentuk catatan lapangan, kemudian disalin dalam bentuk transkip, b) Penyajian data dapat dilakukan dengan tabel, gambar, teks naratif, kerahasiaan dari responden dijamin dengan jalan mengaburkan identitas dari responden, c) Kesimpulan : Dari data yang disajikan, kemudian data di bahas dan dibandingkan dengan hasil-hasil penelitian terdahulu dan secara teoritis dengan perilaku kesehatan. Penarikan kesimpulan dilakukan dengan metode induksi. Data yang dikumpulkan terkait dengan data pengkajian, diagnosis, perencanaan, tindakan dan evaluasi.

\section{HASIL PENELITIAN DAN PEMBAHASAN Pengkajian}

1. Identitas Dan Hasil Anamnesa

Tabel 4.1 Identitas dan Hasil Anamnesa

\begin{tabular}{|c|c|c|c|}
\hline No & $\begin{array}{l}\text { Identitas } \\
\text { Pasien }\end{array}$ & Kasus 1 & Kasus 2 \\
\hline 1. & $\begin{array}{l}\text { Diagnosa } \\
\text { medis }\end{array}$ & $\begin{array}{l}\text { Diabetes } \\
\text { mellitus }\end{array}$ & $\begin{array}{l}\text { Diabetes } \\
\text { mellitus }\end{array}$ \\
\hline 2. & Nama & Ny.S & Ny. N \\
\hline 3. & Umur & 68 Tahun & 62 Tahun \\
\hline 4. & $\begin{array}{l}\text { Jenis } \\
\text { Kelamin }\end{array}$ & Perempuan & Perempuan \\
\hline 5. & Pendidikan & SD & SMP \\
\hline 6. & Status & Menikah & $\begin{array}{l}\text { Belum } \\
\text { menikah }\end{array}$ \\
\hline 7. & Suku & Meandailing & Mandaililng \\
\hline 8. & Alamat & $\begin{array}{l}\text { Cengkeh turi, } \\
\text { Binjai }\end{array}$ & $\begin{array}{l}\text { Jl tembung } \\
\text { gg merpati }\end{array}$ \\
\hline
\end{tabular}




\begin{tabular}{clll}
\hline 9. & Sumber & Auto dan & Auto dan \\
10. & Informasi & Alloanamnesa & Alloanamnesa \\
11. & Tanggal & 08 Februari & 08 Februari \\
& pengkajian & 2021 & 2021 \\
\hline
\end{tabular}

\begin{abstract}
Berdasarkan Tabel 4.1 di dapatkan kedua responden mempunyai diagnose medis yang sama yaitu Diabetes mellitus. Pada kasus 1 berumur 68 Tahun dan pada Kasus 2 berumur 62 Tahun. Pada kasus 1 tingkat pendidikan SD dan kasus 2 SMA .
\end{abstract}

Keluhan utama klien didapatkan bahwa kasus 1 memiliki keluhan utama badan terasa lemas dan kaki terasa kebas sedangkan kasus 2 memiliki keluhan utama badan terasa lemas. Pada kasus 1 memiliki faktor pencetusnya penyakit yang dideritanya DM, dan kasus 2 faktor pencetusnya DM . Pada kasus 1 lama keluhan klien mengalami DM 1 tahun terakhir dan sangat dirasakan 1 minggu terakhir sedangkan kasus 2 lama keluhan klien mengalami DM lamanya 2 tahun. Pada kasus 1 timbul secara timbul secara tiba tiba dan 2 timbul secara bertahap. Pada kasus 1 dan 2 sama - sama memiliki faktor yang memperberat keluhan yaitu meningkatnya kadar gula darah darah yaitu kasus 1 KGD 303 dan kasus ke 2 KGD 409 . Pada kasus 1 dan kasus 2 sama-sama memiliki upaya yang dilakukan yaitu berobat di poliklinik yang ada di UPT.

ADL: didapatkan bahwa pada kasus 1 memiliki pola nutrisi yaitu $B B$ : $45 \mathrm{~kg}$ TB: $148 \mathrm{~cm}$, frekwensi makan $3 \mathrm{x}$ sehari, jenis makanan MB (Makanan Biasa) nasi, lauk, sayur, susu, makanan pantangan makanan yang mengandung tinggi kadar gula, nafsu makanan klien mengatakan baik, dan perubahan BB 6 bulan terakhir klien mengatakan ada perubahan BB selama 6 bulan sedangkan pada kasus 2 memiliki BB : $00 \mathrm{~kg}$ TB : 152 $\mathrm{cm}$, frekwensi makan $3 \times$ sehari , jenis makanan MB (Makanan Biasa) nasi, lauk, sayur, susu, makanan pantangan makanan yang mengandung tinggi kadar garam , nafsu makan klien mengatakan baik, dan perubahan BB 6 bulan terakhir klien mengatakan ada perubahan BB selama 6 bulan. Pada kasus 1 memiliki pola eliminasi yaitu $\mathrm{BAB}$ : Frekwensi $1 \mathrm{x}$ sehari, karakteristik padat, warna kuning kecoklatan dan lembek, riwayat penggunaan pencahar klien tidak menggunakan pencahar dan BAK : Frekwensi sebanyak 7-9 kali sehari dan karakteristik kuning jernih. Pada kasus 1 memiliki pola tidur dan istirahat yaitu waktu tidur 21.00$05.00 \mathrm{WIB}$, lama tidur \pm 9 jam, kebiasaan pengantar tidur klien mengatakan tidak memiliki kebiasaan, kebiasaan selama tidur klien mengatakan tidak ada kebiasaan selama tidur sedangkan kasus 2 memiliki pola tidur dan istirahat yaitu waktu tidur siang (11.00-12.00) malam (24.00-05.00), lama tidur siang (1 jam) malam (4 jam), kebiasaan pengantar tidur klien mengatakan memiliki kebiasaan menonton tv, dan kebiasaan selama tidur tidak ada. Pada kasus 1 memiliki pola aktivitas yaitu pola kegiatan di waktu luang klien mengatakan kegiatannya di waktu luang ialah sholat, keluhan dalam pemenuhan aktivitas klien mengatakan badan lemas, klien tampak lemas, klien tampak terbatas dalam melakukan aktivitas apabila kepala sakit, klien mengatakan tidak dapat melakukan aktivitas apabila kepala sakit, dank lien tampak berjalan lambat dan pelan dan hati-hati berjalan sedangkan pada kasus 2 tidak memiliki pola aktivitas yaitu pola aktivitas di waktu luang, keluhan 
dalam pemenuhan aktivitas klien mengatakan kaki sebelah kiri terasa sakit, klien mengatakan badan lemah, klien mengatakan selalu menggunakan klien tampak lemah, klien tampak memegangi kakinya yang kebas, klien mengatakan kaki sering mengalami kesemutan.

\section{Pengkajian Fisik}

didapatkan bahwa pada kasus 1 pemeriksaan kepala bentuk simetris, keluhan yang berhubungan dengan kepala yaitu klien mengatakan sakit kepala dirasakan apabila tekanan darah meningkat, skala nyeri 3 (010) ringan, dan klien tampak sering memegangi tengah kepalanya, kulit kepala bersih, dan karakteristik rambut sudah tampak sebagian sudah memutih sedangkan kasus 2 pemeriksaan kepala bentuk simetris, keluhan yang berhubungan dengan kepala yaitu klien mengatakan sakit kepala sebelah kanan, klien mengatakan kepala pusing jika tekanan darah meningkat, klien tampak memijat kepala sebelah kanannya, skala nyeri 4 (0-10) nyeri sedang, kulit kepala bersih, dan karakteristik rambut sudah tampak sebagian sudah memutih. Pada kasus 1 dan kasus 2 memiliki kesamaan pada pemeriksaan mata yaitu ukuran pupil isokor $\leq 2 \mathrm{~mm} \mathrm{ka} / \mathrm{ki}$, reflek cahaya baik, pupil mengecil saat diberi cahaya, konjungtiva tidak anemis, sklera unikterik, palpebra baik, dapat membuka dan menutup, tanda radang tidak ada tanda radang terlihat, visus klien hanya dapat melihat dari jarak 4 meter dari pintu, dan penggunaan lensa klien tidak menggunakan lensa. Pada kasus 1 dan kasus 2 memiliki kesamaan pada pemeriksaan hidung yaitu bentuk simetris, polip tidak ada, fungsi penciuman baik, klien masih mampu membedakan baubauannya, reaksi alergi tidak ada, tanda perdarahan tidak ada, dan sinus tidak ada peradangan.
Pada kasus 1 pemeriksaan mulut dan tenggorokan yaitu Gigi geligi berjumlah 15 gigi, klien tidak menggunakan gigi palsu, karies dentis/plague tidak terdapat karies, stomatis tidak ada peradangan, tonsil tidak ada pembesaran, gangguan menelan tidak ada gangguan, gangguan fungsi pengecapan tidak ada gangguan, dan gangguan fungsi wicara tidak ada gangguan sedangkan pada kasus 2 pemeriksaan mulut dan tenggorokan yaitu gigi tampak kutrang lengkap , klien tidak menggunakan gigi palsu , karies dentis/plague tidak terdapat karies, stomatis tidak ada peradangan, tonsil tidak ada pembesaran, gangguan menelan tidak ada gangguan, gangguan fungsi pengecapan tidak ada gangguan, dan gangguan fungsi wicara tidak ada gangguan. Pada kasus 1 dan kasus dua memiliki persamaan dalam pemeriksaan leher yaitu kelenjar thyroid tidak ada pembesaran, bruit sound tidak ada, dan trakeostomy tidak ada. Pada kasus 1dan kasus 2 sama-sama dalam pemeriksaan pernafasan yaitu bentuk thorak simetris, pergerakan pernafasan thoraco abdominal, pola nafas regular, frekwensi pernafasan $20 x / I$, vocal fremitus normal, perkusi lapangan paru resonan, suara abnormal paru tidak dijumpai suara paru tambahan, nyeri dada tidak ada, dan batuk tidak ada. Pada kasus 1 didapatkan status nutrisi dengan balance cairan 325,015 ml sedangkan pada kasus 2 status nutrisi dengan balance cairan 350,015 ml.

Pada kasus 1 dan kasus 2 memiliki persamaan dalam pemeriksaan abdomen yaitu bentuk abdomen simetris, keluhan nyeri tekan tidak ada nyeri tekan, peristaltik usus 10 $x / l$, hepar tidak ada pembengkakan heap, limfa tidak ada pembesaran limfa, masa tumor tidak ada, asites tidak ada, shifting dullness tidak ada, perkusi abdomen tidak 
terdengar suara tambahan, dan spider necvi tidak ada. Pada kasus 1 dan kasus 2 memilki persamaan dalam pemeriksaan anogenetal yaitu gangguan fungsi reproduksi tidak ada gangguan, klien tidak mau menikah lagi, karakteristik mamae mengalami penurunan fungsi, keputihan tidak ada, pembesaran prostat tidak dikaji karena klien perempuan, hernia tidak ada, sekret pada MUE tidak ada, verikokel tidak dikaji karena klien perempuan, hidrokokel tidak dikaji karena klien perempuan, dan wasir tidak ada. Pada kasus 1 dan 2 sama-sama dalam pemeriksaan nerologis yaitu tingkat kesadaran kompos mentis, orientasi baik, dapat mengenal orang dan waktu, memori klien menalami penurunan fungsi memori, sensorium klien mengalami penurunan sensori penglihatan, kemampuan wicara berbicara dengan baik, saraf kranial tidak ada kekakuan, fungsi motorik klien mengalami penurunan fungsi pada ekstremitas bawah, fungsi sensorik klien mengalami penurunan sensori penglihatan, reflek fisiologis tidak ada refle, reflek patologis tidak ada reaksi patologis, dan kaku kuduk tidak ada.

Pada kasus 1 didapatkan dalam pemeriksaan musculoskeletal yaitu kekuatan otot :

Eks sup dex 5 Eks sup sin 5

Eks sup dex 4 Eks sup sin 4 , kekakuan tidak ada, kontraktur tidak ada, spatik tidak ada, flasit tidak ada, dan pola latihan gerak aktif sedangkan pada kasus 2 didapatkan hasil pemeriksaan muskuloskletal yaitu Kekuatan otot:

Eks sup dex 5 Eks sup sin 5

Eks sup dex 4 Eks sup sin 4, kekakuan tidak ada, kфntraktur tidak ada, spatik tidak ada, flasit tidak ada, pola latihan gerak klien melakukan senam lansia pada Selasa dan Jumat, berjalan kaki di sore hari. Pada kasus 1 pemeriksaan integument yaitu warna sawo matang, integritas tampak besisik, turgor baik, $\leq 2$ detik dan suhu $37^{\circ} \mathrm{C}$. kasus 2 pemeriksaan integument yaitu warna sawo matang, integritas tampak baik , turgor baik, $\leq 2$ detik dan suhu $37^{\circ} \mathrm{C}$.

\section{Diagnosa Keperawatan}

Tabel 4.9 Diagnosa Keperawatan

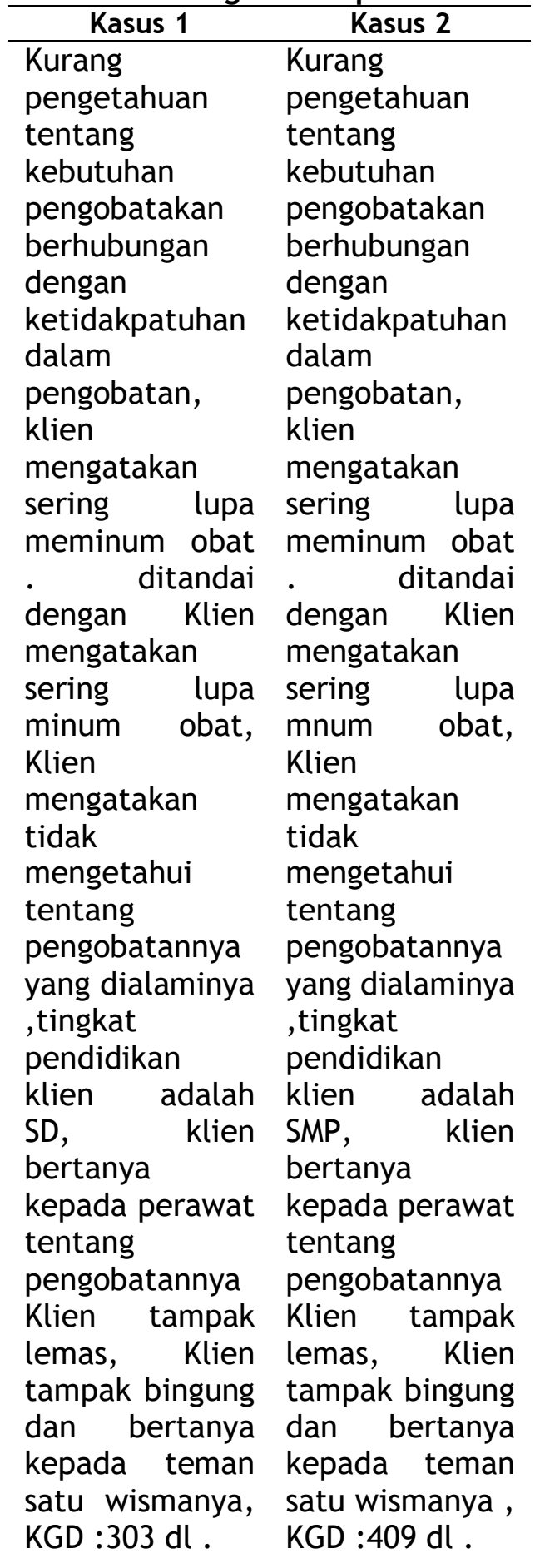




\section{PEMBAHASAN}

Pada pembahasan ini, peneliti akan membahas studi kasus pendidikan kesehatan kepatuhan minum obat diabetes melitus pada Ny.S selama 4 hari dan Ny. N selama 4 hari di UPT Pelayanan Sosial Lanjut Usia Binjai. Kasus ini di mulai dari tanggal 8 Februari 2021 sampai dengan 11 Februari 2021. Dalam hal ini pembahasan yang dimaksud adalah membandingkan antara tinjauan kasus dengan tinjauan pustaka yang disajikan untuk menjawab tujuan khusus dari penelitian. Dimana setiap temuan perbedaan diuraikan dengan konsep dan pembahasan disusun dengan tujuan khusus.

Peneliti melakukan penelitian terhadap dua partisipan yang samasama memiliki penyakit Hipertensi di UPT Pelayanan Sosial Lanjut Usia Binjai dengan 5 tahap sesuai dengan proses keperawatan yang dikembangkan oleh Doengoes yaitu pengkajian, diagnosa keperawatan, perencanaan, implementasi, dan evaluasi. Tujuan khusus trsebut meliputi menggali pngkajian keperawatan, menyususn perencanaan asuhan keperawatan, merumuskan diagnosa keperawatan, melakukan implementasi yang komprehensif, seta melakukan evaluasi keperawatan. Berikut ada pembahasan yang disesuaikan dengan tujuan khusus dari penelitian ini.

\section{Pengkajian}

Adapun kesenjangan antara teori dan kasus pada pengkajian adalah pengkajian didapatkan dari kedua partisipan mempunyai diagnosa medis yang sama yaitu Diabetes melitus yang didasarkan pada meningkatnya kadar gula darah . Diabetes melitus (DM) merupakan penyakit kronis yang umum terjadi pada dewasa yang membutuhkan supervisi medis berkelanjutan dan edukasi perawatan mandiri pada pasien. Namun, bergantung pada tipe DM dan usia pasien, kebutuhuan dan asuhan keperawatan pasien dapat sangat berbeda (LeMone, Bruke \& Bauldoff, 2019).

Berdasarkan hasil pengkajian kedua partisipan memiliki beberapa kesamaan yaitu pada kasus 1 dan dua berjenis kelamin perempuan, pada kasus 1 berumur 68 tahun sedangkan pada kasus 2 berumur 62 tahun. World Health Organization (WHO) memprediksi kenaikan jumlah penyandang DM dari 8,4 juta pada tahun 2000 menjadi sekitar 21,3 juta pada tahun 2030. International Diabetes Federation (IDF) menyatakan bahwa lebih dari 371 juta orang di dunia yang berumur 2079 tahun memiliki diabetes. Indonesia termasuk Negara dengan prevalensi diabetes tertinggi, yaitu urutan ke-7 di bawah China, India, USA, Brazil, Rusia, dan Mexico.

Prevalensi penyakit Diabetes Melitus $\geq 15$ tahun di Provinsi Sumatera Utara pada tahun 2013 berkisar 6,9\% dan meningkat pada tahun 2018 menjadi 8,5\% (Riskesdas, 2018)

Berdasarkan tabel diatas hasil pengkajian kedua memiliki pendidikan yang berbeda. Pada kasus 1 berpendidikan SD sedangkan pada kasus 2 berpendidikan SMA. Menurut Jayanti (2013) menyatakan bahwa pengetahuan atau kognitif merupakan domain yang penting untuk terbentuknya tindakan seseorang. Pengetahuan adalah faktor intern yang mempengaruhi terbentuknya perilaku. Perilaku seseorang tersebut akan berdampak pada status kesehatannya.

Berdasarkan tabel hasil keluhan utama kedua partispan memiliki perbedaan Kasus 1 keluhan utamanya klien mengatakan badannya terasa lemas dan kaki terasa kebas sedangkan kasus 2 
memiliki keluhan utama klien mengatakan badannya lemas . Pada kasus 1 kadar gula darah klien 303 dan pada kasus 2 kadar guka darah klien 409. Berdasarkan hasil ini variabel umur $\geq 50$ dapat meningkatkan kejadian DM tipe 2 karena penuaan menyebabkan menurunnya sensitivitas insulin dan menurunnya fungsi tubuh untuk metabolisme glukosa. Hal tersebut didukung hasil penelitian yang serupa oleh Suastika di Bali didapatkan bahwa prevalensi DM pada kelompok usia tua lebih tinggi tiga kali lipat dibandingkan dengan kelompok yang lebih muda.

Menurut Doengoes (2014) menyatakan bahwa gejala klasik yang diderita pasien diabetes melitus antara lain nyeri kepala, pusing, kelemahan, ansietas, 5P yang berhubungan dengan naiknya kadar gula darah. Gejala yang sering muncul pada diabetes melitus badan terasa lemah .

\section{Diagnosa Keperawatan}

Berdasarkan diagnosa keperawatan yang didapatkan dari kedua responden memiliki diagnosa media yang sama yaitu pendidikan kesehatan kepatuhan minum obat adalah : Kurang pengetahuan tentang kebutuhan pengobatan berhubungan dengan ketidakpatuhan dalam pengobatan, klien mengatakan sering lupa meminum obat . ditandai dengan Klien mengatakan sering lupa mnum obat, Klien mengatakan tidak mengetahui tentang pengobatannya yang dialaminya ,tingkat pendidikan klien adalah SD, klien bertanya kepada perawat tentang pengobatannya Klien tampak lemas, Klien tampak bingung dan bertanya kepada teman satu wismanya , KGD :303 dl .

\section{Rencana Keperawatan}

Berdasarkan tabel 4.8 rencana keperawatan didapatkan dari kedua responden mempunyai rencana keperawatan yang sama. Rencana keperawatan di UPT Pelayanan Sosial Lanjut Usia Binjai hamper sama dengan rencana tindakan pada teori Doengoes (2014). Adapun rencana keperawatan dengan kedua kasus diatas adalah :

Rencana keperawatan yang ada di teori namun tidak ada ada di kasus adalah :

1. Lakukan pendidikan kesehatan kepatuhan minum obat secara bertahap dan sesuai rencana pada satuan acara pembelajaran .

2. Kolaborasi

a) Berikan obat-obat sesuai indikasi, contoh: glibenclamide dan b) Berikan diit DM sesuai indikasi.

3. Tekankan pentingnnya mempertahankan pemeriksaaan gula darah sekali seminggu.

4. Implementasi Keperawatan

Implementasi keperawatan yang dilakukan pada kasus 1 dan kasus 2 tidak terdapat kesenjangan sesuai dengan tindakan yang ada di UPT Pelayanan Sosial Lanjut Usia Binjai.

\section{Evaluasi}

Setelah dilakukan tindakan terhadap pelaksanaan asuhan keperawatan pada kasus 1 dan kasus 2 pada tanggal 8 Februari 2021 sampai 11 Februari 2021 selama 4 hari. Pada kasus I bernama Ny. S dengan masalah keperawatan dengan kurang pengetahuan dalam pengobatan setelah dilakukan selama 4 hari. Dikatakan teratasi sebagian karena dilihat dari pernyataan klien dan observasi perawat yaitu data subjektif klien mengatakan setelah dilakukannya penididkan kesehatan kepatuhan minum obat klien lebih patuh dalam meminum obat ,klien tampak lebih semangat, kemudian dilakukan pemeriksaan tanda-tanda vital hasilnya TD $140 / 80 \mathrm{mmHg}$. $\mathrm{T}: 37^{\circ} \mathrm{C}$, $\mathrm{RR}: 20 \mathrm{x} / \mathrm{i}$, dan HR : $88 \mathrm{x} / \mathrm{i}$. Maka dari pernyataan dan observasi klien disimpulkan bahwa kurang 
pengetahuan mengenal pengobatan teratasi sebagian.

Pada kasus 2 bernama Ny. N dengan diagnose kurang pengetahuan menegenal penyakit, prognosis dan kebutuhan pengobatan setelah dilakukan selama 4 hari. Dikatakan teratasi sebagian karena dilihat dari pernyataan klien dan observasi perawat yaitu data subjektif klien mengatakan setelah dilakukannya penididkan kesehatan kepatuhan minum obat klien lebih patuh dalam meminum obat, klien tampak lebih semangat, kemudian dilakukan pemeriksaan tanda-tanda vital hasilnya TD $140 / 80 \mathrm{mmHg}$. $\mathrm{T}: 37^{\circ} \mathrm{C}$, $\mathrm{RR}: 20 \mathrm{x} / \mathrm{i}$, dan HR : $88 \mathrm{x} / \mathrm{i}$. Maka dari pernyataan dan observasi klien disimpulkan bahwa kurang pengetahuan mengenal penyakit dan prognosis pengobatan teratasi sebagian.

\section{KESIMPULAN}

Setelah penulis melaksanakan asuhan keperawatan pada pasien diabetes mellitus di UPT Pelayanan Sosial Lanjut Usia Binjai Tahun 2020 kepada kasus 1 pada tanggal 8 Februari 2021 sampai 11 Februari 2021, dimana penulis dapat menarik kesimpulan dan memberikan saran yang mungkin dapat bermanfaat bagi pembaca maupun paramedis yang lain.

Adapun kesimpulan tersebut adalah:

4. Pengkajian

Adapun kesenjangan antara teori dan kasus pada pengkajian adalah pengkajian didapatkan dari kedua partisipan mempunyai diagnosa medis yang sama yaitu Diabetes melitus yang didasarkan pada meningkatnya kadar gula darah . Diabetes melitus (DM) merupakan penyakit kronis yang umum terjadi pada dewasa yang membutuhkan supervisi medis berkelanjutan dan edukasi perawatan mandiri pada pasien. Namun, bergantung pada tipe DM dan usia pasien, kebutuhuan dan asuhan keperawatan pasien dapat sangat berbeda (LeMone, Bruke \& Bauldoff, 2019).

Berdasarkan hasil pengkajian kedua partisipan memiliki beberapa kesamaan yaitu pada kasus 1 dan dua berjenis kelamin perempuan, pada kasus 1 berumur 68 tahun sedangkan pada kasus 2 berumur 62 tahun. World Health Organization (WHO) memprediksi kenaikan jumlah penyandang DM dari 8,4 juta pada tahun 2000 menjadi sekitar 21,3 juta pada tahun 2030. International Diabetes Federation (IDF) menyatakan bahwa lebih dari 371 juta orang di dunia yang berumur 2079 tahun memiliki diabetes. Indonesia termasuk Negara dengan prevalensi diabetes tertinggi, yaitu urutan ke-7 di bawah China, India, USA, Brazil, Rusia, dan Mexico.

Prevalensi penyakit Diabetes Melitus $\geq 15$ tahun di Provinsi Sumatera Utara pada tahun 2013 berkisar $6,9 \%$ dan meningkat pada tahun 2018 menjadi 8,5\% (Riskesdas, 2018)

Berdasarkan tabel diatas hasil pengkajian kedua memiliki pendidikan yang berbeda. Pada kasus 1 berpendidikan SD sedangkan pada kasus 2 berpendidikan SMA. Menurut Jayanti (2013) menyatakan bahwa pengetahuan atau kognitif merupakan domain yang penting untuk terbentuknya tindakan seseorang. Pengetahuan adalah faktor intern yang mempengaruhi terbentuknya perilaku. Perilaku seseorang tersebut akan berdampak pada status kesehatannya.

Berdasarkan tabel hasil keluhan utama kedua partispan memiliki perbedaan Kasus 1 keluhan utamanya klien mengatakan badannya terasa lemas dan kaki 
terasa kebas sedangkan kasus 2 memiliki keluhan utama klien mengatakan badannya lemas . Pada kasus 1 kadar gula darah klien 303 dan pada kasus 2 kadar guka darah klien 409. Berdasarkan hasil ini variabel umur $\geq 50$ dapat meningkatkan kejadian DM tipe 2 karena penuaan menyebabkan menurunnya sensitivitas insulin dan menurunnya fungsi tubuh untuk metabolisme glukosa. Hal tersebut didukung hasil penelitian yang serupa oleh Suastika di Bali didapatkan bahwa prevalensi DM pada kelompok usia tua lebih tinggi tiga kali lipat dibandingkan dengan kelompok yang lebih muda.

Menurut Doengoes (2014) menyatakan bahwa gejala klasik yang diderita pasien diabetes melitus antara lain nyeri kepala, pusing, kelemahan, ansietas, 5P yang berhubungan dengan naiknya kadar gula darah. Gejala yang sering muncul pada diabetes melitus badan terasa lemah.

5. Diagnosa Keperawatan

Berdasarkan diagnosa keperawatan yang didapatkan dari kedua responden memiliki diagnosa media yang sama yaitu pendidikan kesehatan kepatuhan minum obat adalah : Kurang pengetahuan tentang kebutuhan pengobatakan berhubungan dengan ketidakpatuhan dalam pengobatan, klien mengatakan sering lupa meminum obat . ditandai dengan Klien mengatakan sering lupa mnum obat, Klien mengatakan tidak mengetahui tentang pengobatannya yang dialaminya ,tingkat pendidikan klien adalah SD, klien bertanya kepada perawat tentang pengobatannya Klien tampak lemas, Klien tampak bingung dan bertanya kepada teman satu wismanya , KGD :303 dl

\section{Rencana Keperawatan}

Berdasarkan tabel 4.8 rencana keperawatan didapatkan dari kedua responden mempunyai rencana keperawatan yang sama. Rencana keperawatan di UPT Pelayanan Sosial Lanjut Usia Binjai hamper sama dengan rencana tindakan pada teori Doengoes (2014). Adapun rencana keperawatan dengan kedua kasus diatas adalah :

Rencana keperawatan yang ada di teori namun tidak ada ada di kasus adalah :

6. Lakukan pendidikan kesehatan secara bertahap dan sesuai rencana pada satuan acara pemebelajaran .

7. Kolaborasi

b) Berikan obat-obat sesuai indikasi, contoh: glibenclamide dan b) Berikan diit DM sesuai indikasi.

8. Tekankan pentingnnya mempertahankan pemeriksaaan gula darah sekali seminggu.

9. Implementasi Keperawatan

Implementasi keperawatan yang dilakukan pada kasus 1 dan kasus 2 adalah pendidikan kesehatan kepatuhan minum obat DM tipe 2, tidak terdapat kesenjangan sesuai dengan tindakan yang ada di UPT Pelayanan Sosial Lanjut Usia Binjai.

10. Evaluasi

Setelah dilakukan tindakan terhadap pelaksanaan asuhan keperawatan pada kasus 1 dan kasus 2 pada tanggal 8 Februari 2021 sampai 11 Februari 2021 selama 4 hari. Pada kasus I bernama Ny. S dengan masalah keperawatan dengan kurang pengetahuan mengenal kepatuhan pengobatan setelah dilakukan selama 4 hari. Dikatakan teratasi sebagian karena dilihat dari pernyataan klien dan observasi perawat yaitu data subjektif klien mengatakan setelah dilakukannya penididkan kesehatan kepatuhan minum obat klien lebih patuh dalam meminum obat ,klien tampak lebih semangat, kemudian 
dilakukan pemeriksaan tanda-tanda vital hasilnya TD 140/80 mmHg. T : $37^{\circ} \mathrm{C}$, RR : $20 \mathrm{x} / \mathrm{i}$, dan HR : $88 \mathrm{x} / \mathrm{i}$. Maka dari pernyataan dan observasi klien disimpulkan bahwa kurang pengetahuan mengenal penyakit dan prognosis pengobatan setelah dilakukan pendidikan kesehatan kepatuhan minum obat klien lebih efektif dalam mengingat.

Pada kasus 2 bernama Ny. N dengan diagnosa Kurang pengetahuan tentang kebutuhan pengobatakan berhubungan dengan ketidakpatuhan dalam pengobatan, klien mengatakan sering lupa meminum obat . ditandai dengan Klien mengatakan sering lupa mnum obat, Klien mengatakan tidak mengetahui tentang pengobatannya yang dialaminya ,tingkat pendidikan klien adalah SMP, klien bertanya kepada perawat tentang pengobatannya Klien tampak lemas, Klien tampak bingung dan bertanya kepada teman satu wismanya, KGD :409 dl . kurang pengetahuan menegenal penyakit, prognosis dan kebutuhan pengobatan setelah dilakukan selama 4 hari. Dikatakan teratasi sebagian karena dilihat dari pernyataan klien dan observasi perawat yaitu data subjektif klien mengatakan setelah dilakukannya penididkan kesehatan kepatuhan minum obat klien lebih patuh dalam meminum obat, klien tampak lebih semangat, kemudian dilakukan pemeriksaan tanda-tanda vital hasilnya TD $140 / 80 \mathrm{mmHg}$. $\mathrm{T}: 37^{\circ} \mathrm{C}$, $\mathrm{RR}: 18 \mathrm{x} / \mathrm{i}$, dan HR : $88 \mathrm{x} / \mathrm{i}$. Maka dari pernyataan dan observasi klien disimpulkan bahwa setelah dilakukan pendididkan kesehatan kepatuhan mimum obat klien lebih efektif dalam mengingat dan lebih patuh dalam minum obat.

\section{DAFTAR PUSTAKA}

Almira, dkk. (2019). Faktor-Faktor yang Berhubungan Dengan Perilaku Kepatuhan Minum obat Anti Diabetes Melitus Tipe 2. Banjarmasin :Jurnal Hoemostatis 2 (1):1-12. https:/ppjp.ulm.ac.id

Adi. Soelistijo, dkk. (2015). Konsensus pengelolaan dan pencegahan Diabetes mellitus tipe 2di Indonesia. PB Perkeni. EGC

Damayanti. Santii. (2015). Diabetes Mellitus \& Penatalaksanaan Keperawatan. Yogyakarta.

Dinarti, dkk. (2013). Dokumentasi Keperawatan. Trans Info Media. Jakarta.

Doenges Marilynn, dkk. (2014). Rencana Asuhan Keperawatan. EGC. Jakarta.

Effendy, Nasrul. (2014). Dasar-dasar Keperawatan Kesehatan Masyarakat. EGC. Jakarta.

Fandinata, S. (2020). Pengaruh Kepatuhan Minum Obat Oral Anti Diabetik Terhadap Kadar Gula Darah Pada Pasien Diabetes Mellitus Tipe II. Jurnal Bidang Ilmu Kesehatan 10 (1):2331.http://ejournal.urindo.ac.id Hannan, Mujib. (2013). Analisis faktor yang Mempengaruhi Kepatuhan Minum Obat pada Pasien Diabetes Melitus .Jambi :Jurnal Kesehatan "Wiraja Medika"9 https//www.ejournalwiraraja.c om

Infodatin. (2018). Hari Diabetes sedunia 2018. http:/pusdatin.kemkes.go.id

Kowalak, dkk. (2016). Buku Ajar Patofisiologi. Jakarta :EGC.

Kurniawaty, dkk. (2016). Faktorfaktor yang Berhubungan Dengan Kejadian Diabetes Melitus Tipe II. Jurnal Majority 5

(2):27- 
31.http:repository.poltekes-

kdi.ac.id

Lemone, dkk. (2019). Buku Ajar Keperawatan Medikal Bedah Gangguan Endokrin. EGC, Jakarta.

Maulana, Heri. (2014). Promosi Kesehatan .Buku Kedokteran EGC, Jakarta.

Mokolomban, dkk. (2018). Kepatuhan Minum Obat pada Pasien Dieabetes Melitus tipe 2 .UNSRAT :Pharmacom.Jurnal Ilmiah Farmasi 7 (4).2018.https: / / ejournal.ac.i d.

Pangaribuan, R., Pangaribuan, N. (2020).Media Pembelajaran Promosi Kesehatan., Bengkulu. El-Markazi

Pangaribuan, R. Nandasari. P (2020). pengaruh terapi perilaku koqnitif terhadap gambaran diri: studi literature.Jurnal Riset Hesti Medan. 5 (1).1619

Priscilla, dkk. (2019). Buku Ajar Keperawatan Medikal Bedah Gangguan Endokrin. EGC, Jakarta.

Rizki, dkk. (2020). Kepatuhan Terhadap Pengobatan Pasien Diabetes Melitus Tipe 2. Jurnal Farmasi Galenika 6(1) : 94-103. https:/bestjournal.untad.a c.id/index.php/Galenatika

Suddarth, brunner. (2014). Keperawatan Medikal Bedah. Jakarta: Penerbit Buku Kedokteran EGC.

Suddarth, brunner. (2019). Keperawatan Medikal Bedah. Jakarta: Penerbit Buku Kedokteran EGC.

Wijaya \& Putri. (2013). Keperawatan Medikal Bedah. Bengkulu. 